Плодоводство и виноградарство Юга России № 52(04), 2018 г.

УДК $634.8: 631: 541.1$

DOI: 10.30679/2219-5335-2018-4-52-139-146

ОСНОВНЫЕ ТЕНДЕНЦИИ

В РАЗРАБОТКЕ АГРОТЕХНИКИ

ВОЗДЕЛЫВАНИЯ МАТОЧНЫХ

НАСАЖДЕНИЙ ПОДВОЙНЫХ ЛОЗ ВИНОГРАДА

Михайловский Станислав Сергеевич мл. научный сотрудник

Анапская зональная опьтная станции виноградарства и виноделия филиал Федерального государственного бюджетного научного учреждения «Северо-Кавказский федеральный научныи ичентр садоводства, виноградарства, виноделия», Анапа, Россия

Петров Валерий Семенович ${ }^{1}$ д-р с.-х. наук

зав. функциональным научным центром «Виноградарство и виноделие»

Федеральное государственное бюджетное научное учреждение «Северо-Кавказский федеральный научный иентр садоводства, виноградарства, виноделия», Краснодар, Россия

Первостепенное значение в мероприятиях по повышению эффективности возделывания подвоев винограда играет способ формирования и ведения маточных кустов.

Формирование кустов -важнейший агротехнический прием, с помощью которого регулируют рост и развитие растений, качество посадочного материала. Лучшим считается способ формирования кустов, при котором с единицы площади обеспечивается наибольший выход качественных черенков при наименьших затратах. Теоретическую основу выбора форм кустов винограда в маточниках подвойных лоз определяют следующие
UDC $634.8: 631: 541.1$

DOI: 10.30679/2219-5335-2018-4-52-139-146

\section{THE MAIN TRENDS \\ IN THE AGROTECHNICAL CULTIVATION FOR NURSERY PLANTATION OF GRAPEVINE ROOTSTOCKS}

Mikhaylovskiy Stanislav Sergeyevich Junior Research Associate

Anapa Zonal Experimental

Station of Viticulture and Wine-making Branch of Federal State Budgetary

Scientific Institution

"North-Caucasus Federal

Scientific Center of Horticulture, Viticulture, Winemaking», Anapa, Russia

Petrov Valeriy Semionovich

Dr. Sci. Agr.

Head of the Functional Scientific Center of «Viticulture and Wine-making»

Federal State Budget

Scientific Institution

"North Caucasian Federal

Scientific Center of Horticulture,

Viticulture, Wine-making»,

Krasnodar, Russia

The method of formation and maintenance of bushes in the nursery plays a primary role in the measures to increase the efficiency of rootstock cultivation. The formation of bushes is an important agrotechnical mode, regulated the growth and development of plants and the quality of planting material. The best way of bushes formation, is the way when the greatest yield of qualitative cuttings is ensured from an unit of area at the lowest cost. The following main principles determine the theoretical basis for choosing the forms of grape bushes in the nursery of vine rootstocks: they are the construction of bushes

\footnotetext{
${ }^{1}$ Научный руководитель
} 
основные принципы: конструкция кустов и биология используемых сортов должны быть максимально адаптированы к местным условиям произрастания, смягчать отрицательное влияние абиотических стрессоров, отвечать сортовым особенностям, быть удобной для выполнения ручных и механизированных работ. Целью данной работы является Теоретическое обоснование Разработки эффективных приемов Выращивания маточных насаждений подвойных сортов винограда, обеспечивающих повышение выхода и качества стандартных черенков в условиях привитой культуры. Данное исследование заключалось в обзоре отечественной и зарубежной литературы, статей, докладов и электронных источников (журналы, книги и сайты) по данной тематике, связанной с формированием маточников подвойных лоз винограда. Несмотря на наличие большого разнообразия форм и способов ведения кустов винограда имеется ряд недостатков, отрицательно влияющих на качество и выход черенков с единицы площади, затрудняется борьба с болезнями и вредителями. Поэтому в настоящее время создание и разработка новых ресурсосберегающих способов ведения маточников подвойных лоз для производства высококачественных черенков является одной из актуальных задач в отрасли виноградного питомниководства.

and the biology of the varieties used should be maximally adapted to local conditions of growth, to desrease in the negative influence of abiotic stressors, to respond to varietal characteristics, and to be convenient for manual and mechanized work. The purpose of this work is the theoretical substantiation of the development of effective methods of plantations growing grape nursery that provide an increase in the yield and quality of standard cuttings under conditions of the grafted crop cultivation. This study consisted of a review of Russian and foreign literature, articles, reports and electronic sources (magazines, books and websites) on this subject, related to the formation of wine rootstock nursery plantation. Despite the existence of a wide variety of forms and ways of vine bushes keeping, there are a number of deficiencies that adversely affect the quality and yield of cuttings from an unit area, and making it more difficult to control the diseases and vermins. Therefore, at present, the creation and development of new resource-saving ways of vine rootstock nursery maintaining for the production of high-quality cuttings is one of the urgent tasks in the field of grape nursery keeping.

Ключевые слова: ПОДВОЙ, ШПАЛЕРА, Key words: ROOTSTOCK, TRELLIS, ФОРМИРОВКА, СОРТ, ВИНОГРАД FORMING, VARIETY, GRAPES

Введение. Маточник подвойных лоз служит для заготовки черенков подвоя, используемых в процессе прививки при производстве привитого посадочного материала, и является обязательной составной частью виноградного питомника в районах привитой культуры. Первостепенное значение в мероприятиях по повышению эффективности возделывания подвоев играет 
Плодоводство и виноградарство Юга России № 52(04), 2018 г.

способ формирования и ведения маточных кустов винограда. Формирование кустов - это важнейший агротехнический прием, с помощью которого регулируют рост и развитие кустов, производительность и качество посадочного материала. Лучшим считается тот способ формирования и ведения кустов, при котором с единицы площади обеспечивается наибольший выход качественных черенков при наименьших затратах $[1,2]$.

Теоретическую основу выбора форм кустов винограда в маточниках подвойных лоз определяют следующие основные принципы: конструкция кустов и биология используемых сортов должны быть максимально адаптированы к местным условиям среды произрастания, смягчая отрицательное влияние абиотических стрессоров на растения винограда (критических низких и высоких температур, заморозков, засухи, повышенной влажности воздуха и др.), отвечать сортовым особенностям, быть удобной для выполнения ручных и механизированных работ.

Основной целью данной работы является теоретическое обоснование и разработки эффективных приемов выращивания маточных насаждений подвойных сортов винограда, обеспечивающих повышение выхода и качества стандартных черенков в условиях привитой культуры.

Объекты и методы исследований. Данное исследование заключалось в обзоре отечественной и зарубежной литературы, статей, докладов и электронных источников (журналы, книги и сайты), связанные с формированием маточников подвойных лоз винограда.

Обсуждение результатов. В естественном (диком) состоянии виноград представляет собой лиану. На культивируемых виноградниках многоствольной лиане придают вид куста для удобства ухода и механизации трудоемких процессов, повышения продуктивности насаждений и качества продукции. В зависимости от наличия и характера развития штамба, головы и рукавов, составляющих стеблевой скелет растения, кусты имеют ту или 
иную форму. Наиболее распространенные формы куста: головчатая, чашевидная (малая крымская, средняя украинская и большая молдавская чаши), односторонняя (кахетинская, или одноплечий Гюйо), веерная (малая четырехрукавная, средняя шести-восьмирукавная и большая среднеазиатская веерная формировки), полувеерная, кордон (горизонтальный, наклонный и вертикальный) [3].

В начале промышленного возделывания подвойных лоз многие авторы научных работ придерживались мнения о предпочтительности низких форм подвойных кустов - головчатая или короткорукавная формировки без штамба. По данным В.Г. Николенко и Ю.В. Войнова [4] во всех случаях при отклонении побегов растений от вертикального к горизонтальному положению снижается рост, и доминирующими становятся процессы развития. Аналогичные данные получены и другими авторами (Козлов, 1974; Зеленухин, 1979; Лихолат, 1983), Синот, а позже Ф.М. Куперман [5], считают, что из почки большего диаметра получается больших размеров сердцевина побега, что крайне нежелательно для маточников подвойных лоз. Поэтому для получения наибольшего прироста подвойные сорта винограда обрезают преимущественно по системе головчатой формы. При этом для уменьшения скелетных частей штамб делают высотой не более 50 сантиметров. О том же говорит и зарубежный опыт возделывания подвоев в Германии, в Италии (по А. С. Мелконяну) [6], во Франции по Е. Шанкрену и Ж. Лонгу [7].

М.В. Мелконян и др. [6] акцентируют внимание на том, что агротехнические приемы должны быть различны для плодоносящих и лозоносящих маточников. Согласно физико-химической закономерности следует активизировать процессы развития и роста соответственно, поэтому получение максимума полуметровых черенков возможно за счет компенсаторного роста в случае удаления всей надземной части растения на «черную головку» с оставлением самых угловых спящих почек и при вертикальном росте по- 
Плодоводство и виноградарство Юга России № 52(04), 2018 г.

бегов. В то же время при компенсаторном росте образуется большое количество пасынков, что увеличивает затраты на их удаление.

В Югославии маточник возделывают в расстил, при головчатой формировке, на Украине также используется способ ведения подвойных кустов в расстил, при котором растущие побеги распределяются на поверхности почвы пучками вдоль рядов [8]. В данном случае очень трудно вести борьбу с сорняками, вредителями и болезнями, проводить пасынкование, лоза повреждается некрозом и антракнозом.

Революционным метод для возделывания маточников был предложен Л. Мозером [9], который в целях снижения затрат труда по уходу за маточными кустами подвоев предложил высокоштамбовую форму. При штамбе высотой 1,5 м и двухстороннем кордоне растущие побеги свободно свисают вниз. При этом увеличивается количество лоз, но уменьшается длина каждой, что позволяет увеличить количество высококачественных черенков, нарезанных из нижней и средней части побега.

Исследования Л.М. Малтабара [10] показали, что увеличение выхода лозы в районах недостаточного увлажнения можно получить, применяя короткорукавную веерную формировку с постоянным омолаживанием рукавов. Также предложена штамбовая форма высотой 0,60 м на горизонтальной шпалере. Н.Д. Перстневым и О.П. Морием [11] установлена обратная взаимосвязь между объемом многолетней древесины и величиной однолетнего прироста куста. В то же время качество лозы на штамбовых маточниках выше, чем на приземистых. Следовательно, при формировании маточных кустов отношение между однолетним приростом и многолетней древесиной должно устанавливаться в конкретных почвенно-климатических условиях индивидуально. А.П. Терещенко [12] предложил использовать форму кустов «зеленый фонтан», при которой побеги развиваются горизонтально, 
Плодоводство и виноградарство Юга России № 52(04), 2018 г.

подвязанные в рыхлый пучок к горизонтальной шпалере, но этот способ требует очень своевременного проведения пасынкований, затрудняет борьбу с болезнями и вредителями, и самое главное - нижняя часть побегов плохо вызревает из-за затенения верхней частью лозы. С.И. Страту [13] говорит, что выращивание лозы для черенков на штамбовых формировках улучшает качество древесины, способствует лучшему вызреванию побегов (на 8485\% длины прироста). При использовании черенков для прививки достигается высокий выход стандартных саженцев.

А. Г. Мишуренко отмечает, что высоко-штамбовая форма со свисающим приростом обеспечивает высокий выход черенков с единицы площади, при минимальных затратах труда и материальных средств.

Ю.А. Белинский [14] предложил возделывать кусты сорта Берландиери х Рипариа Кобер 5ББ на вертикальном одностороннем кордоне с оставлением рожков на высоте 0,70 и 1,30 м. Такая форма требует невысокую шпалеру и два яруса проволоки. А.Г. Палеха [15] на основе 3-х летнего опыта по сорту Шасла х Берландиери 41 Б показал, что наибольший выход подвойной лозы обеспечивают кусты, сформированные в виде короткорукавного веера на вертикальной шпалере.

Е.Г. Подгорный, В.А. Богданов, Л.И. Бессараб [16] изучали влияние формировок сорта Берландиери х Рипариа СО4: головчатой, короткорукавной веерной, одноплечего кордона и высокоштамбовой формировки - на выход подвойных черенков. Наибольший выход черенков наблюдался при коротко-рукавной веерной формировке. Высокоштамбовая же форма (1,71,8 м.) со свободным свисанием прироста дала лучшие показатели по степени вызревания по сравнению с другими формировками, но и наименьший выход подвойных черенков. Предложенный Л.М. Малтабаром [10] метод ведения подвойных кустов на Т- или П-образной шпалере требует проведения очень частых пасынкований, затрудняет борьбу с болезнями, лоза неравномерно вызревает. 
Плодоводство и виноградарство Юга России № 52(04), 2018 г.

Bbыводы. Таким образом, несмотря на наличие большого разнообразия форм и способов ведения кустов винограда имеется ряд недостатков, отрицательно влияющих на качество и выход черенков с единицы площади, затрудняется борьба с болезнями и вредителями. Поэтому в настоящее время создание и разработка новых ресурсосберегающих способов ведения маточников подвойных лоз для производства высококачественных черенков является одной из актуальных задач в отрасли виноградного питомниководства. Для этого необходимо усилить исследования и установить биологические закономерности роста и развития подвойной лозы; разработать эффективную систему ведения маточников подвоя, а также выявить влияние различных форм маточных кустов на рост и развитие виноградных растений.

\section{Литература}

1. Маточники винограда: рекомендации для виноградарских хозяйств Краснодарского края. - Краснодар, 2000. - 52 с.

2. Stanko, Vršiča. Factors influencing grafting success and compatibility of grape rootstocks / Stanko Vršič, Borut Pulko, Laszlo Kocsis // Scientia Horticulturae, Vol. 181, 2015, Pages 168-173.

3. Смирнов, К.В. Виноградарство / К.В. Смирнов, Л.М. Малтабар, А.К. Раджабов, Н.В. Матузов. - М., 1998. - С. 334-352.

4. Николенко, В.Г. Культура маточников подвойных лоз в Крыму / В.Г. Николенко, Воинов Ю.В. // Виноделие и виноградарство СССР. - 1979. - № 2. - С. 37-40.

5. Куперман, Ф.М. Морфо физиология растений. Морфофизиологический анализ этапов органогенеза различных жизненных форм покрытосеменных растений / Ф.М. Куперман. - 3-е изд.- перераб. и доп. -М.: Высшая школа, 1977. - 288 с.

6. Мелконян, М.В. Виноградарство Италии / М.В. Мелконян. - Москва, 1971. - 96 с.

7. Шанкрен, Е. Виноградарство Франции / Е. Шанкрен, Ж. Лонг. - Киев: Урожай, 1961. - С.142-145.

8. Николенко, В.Г. Выращивание виноградных саженцев / В.Г. Николенко. - М., 1982. $-23 \mathrm{c}$.

9. Мозер, Л. Виноградарство по-новому / Л. Мозер. - Москва, 1961. - С. 86-88.

10. Малтабар, Л.М. Виноградный питомник / Л.М. Малтабар, Д.И. Казаченко. Краснодар, 2009. - 290 с.

11. Перстнёв, Н.Д. Виноградарство / Н.Д. Перстнев. - Кишинёв: Агропромиздат, 2001. - C. 326-330.

12. Терещенко, А.Г. Новое в формировании подвойной лозы винограда / А.Г. Терещенко // Виноград и вино России. - 1992. - № 5. - С. 29-31.

13. Страту, С.И. Формирование виноградных кустов по штамбовой системе / С.И. Страту // Садоводство, виноградарство и виноделие Молдавии. - 1975. - № 4. C. 51-55. 
14. Белинский, Ю.А. Технолопя виробництва чубуюв винограду / Ю.А. Белинский // Аграрна наука - виробництву. - 2000. - № 3. - С. 31.

15. Палеха, А.Г. Влияние формировки и типа опоры на выход и качество подвойной лозы сорта Шаслах Берландиери 41Б / А.Г. Палеха // Проблемные вопросы индустриального возделывания винограда и его промышленной переработки. Виноградарство. Часть І. - Ялта, 1985. - С. 21-22.

16. Подгорный, Н.Д. Способы формирования подвойных кустов сорта С04 / Н.Д. Подгорный, В.А. Богданов, Л.И. Бессараб // Садоводство, виноградарство и виноделие Молдавии. - 1984. - №4. - С. 73-75.

\section{References}

1. Matochniki vinograda: rekomendacii dlya vinogradarskih hozyajstv Krasnodarskogo kraya. - Krasnodar, 2000. - 52 s.

2. Stanko, Vršiča. Factors influencing grafting success and compatibility of grape rootstocks / Stanko Vršič, Borut Pulko, Laszlo Kocsis // Scientia Horticulturae, Vol. 181, 2015, Pages 168-173.

3. Smirnov, K.V. Vinogradarstvo / K.V. Smirnov, L.M. Maltabar, A.K. Radzhabov, N.V. Matuzov. - M., 1998. - S. 334-352.

4. Nikolenko, V.G. Kul'tura matochnikov podvojnyh loz v Krymu / V.G. Nikolenko, Voinov YU.V. // Vinodelie i vinogradarstvo SSSR. - 1979. - № 2. - S. 37-40.

5. Kuperman, F.M. Morfo fiziologiya rastenij. Morfofiziologicheskij analiz ehtapov organogeneza razlichnyh zhiznennyh form pokrytosemennyh rastenij / F.M. Kuperman. 3-e izd.- pererab. i dop. -M.: Vysshaya shkola, 1977. - 288 s.

6. Melkonyan, M.V. Vinogradarstvo Italii / M.V. Melkonyan. - Moskva, 1971. $96 \mathrm{~s}$.

7. SHankren, E. Vinogradarstvo Francii / E. SHankren, ZH. Long. - Kiev: Urozhaj, 1961. - S.142-145.

8. Nikolenko, V.G. Vyrashchivanie vinogradnyh sazhencev / V.G. Nikolenko. M., 1982. -23 s.

9. Mozer, L. Vinogradarstvo ponovomu / L. Mozer. - Moskva, 1961. - S. 86-88.

10. Maltabar, L.M. Vinogradnyj pitomnik / L.M. Maltabar, D.I. Kazachenko. - Krasnodar, 2009. - $290 \mathrm{~s}$.

11. Perstnyov, N.D. Vinogradarstvo / N.D. Perstnev. - Kishinyov: Agropromizdat, 2001. - S. 326-330.

12. Tereshchenko, A.G. Novoe v formirovanii podvojnoj lozy vinograda / A.G. Tereshchenko // Vinograd i vino Rossii. - 1992. - № 5. - S. 29-31.

13. Stratu, S.I. Formirovanie vinogradnyh kustov po shtambovoj sisteme / S.I. Stratu // Sadovodstvo, vinogradarstvo i vinodelie Moldavii. - 1975. - № 4. - S. 51-55.

14. Belinskij, YU.A. Tekhnolopya virobnictva chubuyuv vinogradu / YU.A. Belinskij // Agrarna nauka - virobnictvu. - 2000. - № 3. - S. 31.

15. Palekha, A.G. Vliyanie formirovki i tipa opory na vyhod i kachestvo pod vojnoj lozy sorta SHaslah Berlandieri 41B / A.G. Palekha // Problemnye voprosy in dustrial'nogo vozdelyvaniya vinograda i ego promyshlennoj pererabotki. Vinogradarstvo. Chast' I. - Yalta, 1985. - S. 21-22.

16. Podgornyj, N.D. Sposoby formirovaniya podvojnyh kustov sorta S04 / N.D. Podgornyj, V.A. Bogdanov, L.I. Bessarab // Sadovodstvo, vinogradarstvo i vino delie Moldavii. 1984. - №4. - S. 73-75. 